\title{
Minangkabau's Women in Kaba Sabai Nan Aluih: Ragam Orang
}

\author{
Aimifrina Aimifrina ${ }^{1}{ }^{*}$, Tammasse Tammasse ${ }^{2}$ \\ ${ }^{1}$ Student of Indonesian Literature Study Program, Faculty of Cultural Sciences, \\ Hasanuddin University \\ ${ }^{2}$ Lecturer of Indonesian Literature Study Program, Faculty of Cultural Sciences, Hasanuddin \\ University \\ * Corresponding author. Email: aimifrina@yahoo.co.id
}

\begin{abstract}
The purpose of this study is to explain Minangkabau's women in Kaba Sabai Nan Aluih seen from ragam orang in Minangkabau culture. Ragam orang is a personal human judgment that departs from the teachings of Minangkabau philosophy. There are four categories of ragam orang which are orang, takah orang, angkuh orang, and orang-orang. The results of this study concluded that Minangkabau's women in kaba Sabai Nan Aluih belong to ragam orang with categories of orang. Orang are normal people who feel the bad and good, the high and low, the dark and light just like everyone else. Then feel ashamed if you can't be the same as other people.
\end{abstract}

Keywords: Minangkabau's women , kaba, ragam orang

\section{INTRODUCTION}

Minangkabau as a tribe in Indonesia have a difference in culture (adat) that distinguish them from other tribes in Indonesia. Culture (adat) for Minangkabau people divided into four, namely (1) adat yang sebenarnya adat; (2) adat istiadat; (3) adat yang diadatkan; (4) adat yang teradat. In addition to having these four adat, the Minangkabau people also has a law known as Undang-Undang nan Empat. Undang-undang nan Empat are (1) undangundang nagari, (2) undang-undang isi nagari, (3) undang-undang luhak dan rantau, dan (4) undang-undang dua puluh. This law regulates all aspects of government and public life as well as order [1].

One of the undang-undang nan empat, namely undang-undang isi nagari is a life lessons, which covers a view of life or philosophy, ethics, and morals supported by a strong motivation, so that it has its national pride. This law emphasizes the relationship between humans and humans directly or indirectly. For example in the kinship system, marriage, inheritance, ethics, and morals along with their values [1].

Ethical and moral issues and their values are related to personal human problems. This provides an assessment of how the human person is. The assessment is determined based on three main scales which are samo (sesama), raso (serasa), dan malu (semalu). These three things has a different response and appreciation for everyone because the basis are different. There are people who are able to live with all those three things, there are also those who are only able to live with two or one of the three things. From that point of view, humans are divided into four types, namely (1) orang, namely normal people who feel the bad and the good, the high and the low, the dark and the light like other people. And feel ashamed if you can't be the same as others; (2) takah orang, namely people who seem like 
normal people, but do not have a fixed attitude or who like to go along with the direction of the strong wind; (3) Angkuh orang are people who pretend to know like other people, but actually they don't understand what other people understand. This man has no shame; (4) Orang-orang, namely people who are like scarecrows (dolls) in the fields, who cannot move on their own who always need other people. They are the same as a fool [1] .

One of the methods to determine about ragam orang in the life of the Minangkabau people is to analyze kaba. Kaba is a form of Minangkabau oral literature whose dissemination to the community is carried out by tukang kaba. Tukang kaba tell stories (bakaba) accompanied by traditional music, such as saluang, rabab, even sometimes only using small objects such as matches that are played skillfully by tukang kaba (Udin, 1989:1). According to [2] $k a b a$ is a rhythmic prose story in the form of a narrative and is classified as a long story, similar to the Sundanese pantun. In terms of story content, $k a b a$ is the same as a saga in old Indonesian literature or a novel in modern Indonesian literature.

According to Bakar [3] kaba is a type of literature that has to do with an event and ceremony, namely as a complementary tool for a party or wedding ceremony. In addition to dealing with the events and ceremonies of the traditional society, this literary form $(k a b a)$ also describes and originates from the philosophy that lives in society. Kaba contains many cultural values [2].

One of the famous kaba in Minangkabau is the kaba Sabai Nan Alui. Through this kaba, it can be known the culture contained in Minangkabau society, especially ragam orang in the society. Ragam orang can be seen from the characters in the $k a b a$ with their respective roles. These figures are Sabai Nan Aluih, Mangkutak Alam, Rajo Babandiang, Rajo Nan Panjang, and Sadun Saribai. Of the five figures analyzed only female characters which is Sabai Nan Aluih (child) and Sadun Saribai (mother). These two women in Minangkabau society have different name. Sabai Nan Aluih has not been called bundo kanduang because she is not married yet. Thus, those who can be called as bundo kanduang and mande sako are Sadun Saribai (Sabai Nan Aluih's mother). Bundo Kanduang or mande sako is an absolute title for married women, as well as the highest hierarchy in the ethnic structure of adherents of the matrilineal system, kinship or lineage prevailing in Minangkabau. Matrilineal is the arrangement of kinship based on the mother's line. While bundo kanduang is the central figure in the family. All family matters were left to him. She is the determiner of wisdom in the family. The figure of Bundo Kanduang is essentially the ideal values of Minangkabau women themselves. This is in accordance with what Aimifrina [4] said that there are many interesting things in the life of the Minangkabau people. A picture of the life of the Minangkabau people who respect customs in their daily lives.

Based on the description above, researcher is interested in examining ragam orang in $k a b a$ Sabai Nan Aluih, especially female characters. The ragam orang are orang, takah orang, angkuh orang, and orang-orang. Thus, it will be known the culture that exists in kaba Sabai Nan Aluih which indirectly describes the culture of the Minangkabau people.

\section{METHODS}

Based on the methodology design, this research is belong to document research (content analysis). Content Analysis tries to analyze the document to find out the content and meaning contained in the document. Types of documents include written essays, pictures, textbooks, newspapers, films, dramas, and bulletins [5].

The method used in this research is descriptive analysis method. Descriptive method of analysis is done by describing the facts which are then followed by analysis [6].

The sources of the data in this study is the written data. The written data is kaba Sabai Nan Alui. Kaba was written by M. Rasyid Manggis Dt. King King. Kaba Sabai Nan Alui was published by Kristal Multimedia in 2004 in Bukittinggi and was the first printing. This 
$k a b a$ is 72 pages thick. The language used in this kaba is Minangkabau language.

\section{RESULTS AND DISCUSSION}

Kaba Sabai Nan Aluih has two female characters which is Sabai Nan Aluih and Sadun Saribai. The two figures will be analyzed from ragam orang. Here's the analysis.

\subsection{Sabai Nan Aluih}

Sabai Nan Aluih is the main character in kaba Sabai Nan Aluih and the son of Sadun Saribai. Ragam orang from Sabai Nan Aluih can be seen in the data below.

Data 1

\author{
"Denai tiliak denai \\ pandangi, anak rintang \\ di ateh anjuang sajo, \\ rintang malukih jo \\ batanun (hlm.11-12).
}

I see that the child is

busy with painting and

weaving on the anjuang.

The first data is the assessment of Mrs. Sabai Nan Aluih (Sadun Saribai) towards Sabai Nan Aluih, her son. Sabai Nan Aluih as a Minangkabau woman diligently paints and works to make woven items. It can be concluded that Sabai Nan Aluih knows how to be a Minangkabau woman which skilled at working on women's skills and diligent in working. Thus, Sabai Nan Aluih can be grouped into ragam orang with categories of orang. It means normal people who feel the bad and the good, the high and the low, the dark and the light like everyone else. Sabai Nan Aluih knows to place herself as a Minangkabau woman, namely working on the skills of women in Minangkabau which is weaving.

Data 2

Tuanku Rajo Nan Panjang, batanyo denai sakaciak, usah denai tuan bodohkan, lah nyato denai parampuan, tuan lah nyato laki-laki, tuan bunuah koh bapak denai, apo sabab karanonyo...

"Adiak denai Sabai Nan Aluih, bukannyo salah dari denai, salah di bapak adiak juo, saelok itu denai datang, diantakan siriah dangan pinang, kok adat nak denai isi, limbago nak denai tuang, manuruik langgan Padang Tarok. Tapi ruponyo di bapak adiak, adok siriah nan lah datang, tampuaknyo indak digutiah, ujungnyo indak dicabiak, lai koh rajo maulak sambah? (hlm. 5556).

My lord Rajo Nan Panjang, I want to ask something, don't fool me, it's obvious that I am a woman, and you are also a real man, you killed my father, why?...

"My sister Sabai Nan Aluih, it's not my fault, it's your brother's fault, as well as that I came, delivered betel nut with areca nut, how come I didn't fill in the adat, I didn't pour the limbago, according to Lombago Padang Tarok. But apparently in the father and sister, the betel tradition that comes, the appearance is not thinned, the ends are not torn off, does the king's worship rejected?

The second data are the conversation of Sabai Nan Aluih with Rajo Nan Panjang, the man who killed her father "batanyo denai sakaciak, usah denai tuan bodohkan, lah nyato denai parampuan, tuan lah nyato laki-laki, tuan bunuah koh bapak denai, apo sabab karanonyo (I want to ask something, don't fool me, it's obvious that I am a woman, and you are also a real man, you killed my father, 
why?). From this statement it can be concluded that Sabai Nan Aluih has a brave character. This courageous character classifies Sabai Nan Aluih into ragam orang with categories of orang. Orang are normal people who feel the bad and the good, the high and the low, the dark and the light just like everyone else. Sabai Nan Aluih felt bad for his father because his father was killed by Rajo Nan Panjang. Sabai Nan Aluih could not accept the bad situation before she received an explanation of the cause of her father's death. So that the bad becomes good, and the dark becomes light, Sabai Nan Aluih must dare to ask the person who killed her father which is Rajo Nan Long.

Data 3

Lah berang bangih Sabai Nan aluih, "Adat limbago parampuan, pandai bainai di ujuang kuku, pandai bainai di ujuang karih. Adat limbago laki-laki, pandai basilek jo manembak, indak jadi batulang lamah, indak buliah badarah bali, tabujua lalu tabalintang patah.

Manjawab juo Mangkutak Alam, bakato sambia jo takuik, "Jan lah aciak bangih juo, denai indak pandai malapeh badia, aciak lah samo tahu juo, denai biaso baalang-alang... (hlm. 66).

Sabai Nan was angry, "It is customary for women's institutions to be good at embroidering at the tip of the nail, clever at dressing at the tip of the kris. The custom of male institutions, good at martial arts and shooting, must not have weak bones, must not be of Balinese blood, lie down and then break apart.

\author{
Replying to Mangkutak \\ Alam, he said timidly, \\ "Don't be angry too, I'm not \\ good at removing guns, \\ aciak already know, I used \\ to play a kite..
}

The third data is a conversation between Sabai Nan Aluih and her brother Mangkutak Alam. "Lah berang bangih Sabai Nan aluih, "Adat limbago parampuan, pandai bainai di ujuang kuku, pandai bainai di ujuang karih. Adat limbago laki-laki, pandai basilek jo manembak, indak jadi batulang lamah, indak buliah badarah bali, tabujua lalu tabalintang patah (Sabai Nan Aluih was angry, "It is customary for women's institutions to be good at embroidering at the tip of the nail, clever at dressing at the tip of the kris. The custom of male institutions, good at martial arts and shooting, must not have weak bones, must not be of Balinese blood, lie down and then break apart). This conversation discusses how customary institutions in Minangkabau are for girls and boys. Sabai Nan Aluih was angry with her younger brother because her younger brother was not in accordance with what was stipulated by the berlimbago custom, which was good at martial arts, good at hunting, firm, not to be afraid, and had principles. From this conversation, it can be seen that Sabai Nan Aluih's character is firm towards her brother. With her assertive character, Sabai Nan Aluih includes ragam orang with the category of orang because they know what is bad and what is good according to people's understanding. Orang are normal people who feel the bad and the good, the high and the low, the dark and the light just like everyone else. The person will feel ashamed if he can not be the same as other people. Sabai feels ashamed if his younger brother doesn't conform to the custom of the limbo in Minangkabau.

Data 4 
tapakua maso nantun, hati sadiah indak tabado, bagai diirih dangan sambilu, bapak manampuah pasawangan (hlm. 26).

Hearing the incomparable lightning, Sabai Nan Aluih already understood, submissive and pensive at that time, her heart was very sad, like being sliced with a knife, father headed to a quiet and dangerous place.

The fourth data is the behavior of Sabai Nan Aluih which can be seen from the "tapakua maso nantun" (pensive at the time). The pensive behavior at that time was carried out by Sabai Nan Aluih because her father headed to a quiet and dangerous place. This quote explains the anxious character of Sabai Nan Aluih that something will happen to her father. With this pensive behavior, Sabai Nan Aluih can be grouped into ragam orang with categories of orang. It means normal people who feel the bad and the good, the high and the low, the dark and the light like everyone else. Sabai Nan Aluih felt that something bad would happen to her father because his father headed to a quiet and dangerous place to meet Rajo Nan Panjang because Rajo Nan Panjang could not accept his proposal being rejected. For that Rajo Nan Panjang invites Mr. Sabai Nan Aluih to fight.

Data 5

Kununlah anak gubalo, sapatah indak manyahuik, inyo lah samo tahu juo, Sabai Nan aluih urang nan arif, tahu di baying kato sampai, nan tampak alah dihimbaukan, puehlah raso dalam hati (hlm. 46).
It is said that the shepherd child, some did not answer, he already knew, Sabai Nan Aluih was a wise person, knew the word until, which seemed to have been appealed, was satisfied in his heart.

The fifth data is someone else's assessment of Sabai Nan Aluih. This can be seen from the quote "inyo lah samo tahu juo, Sabai Nan aluih urang nan arif" (she already knows, Sabai Nan Aluih is a wise person). This opinion explains that Sabai Nan Aluih has a wise character. Thus, Sabai Nan Aluih includes a variety of ragam orang with categories of orang. Orang are normal people who feel the bad and the good, the high and the low, the dark and the light as other people according to the wisdom possessed by Sabai Nan Aluih, which is being able to understand, know, and understand other people.

\subsection{Sadun Saribai}

Sadun Saribai is the mother of Sabai Nan Aluih. Ragam orang from Sadun Saribai can be seen in the data below.

Data 1

Sabagai lai nak kanduang, alah koh anak tahu pandai, adat limbago parampuan, adat bakorong jo bakampuang?

Manjawab Sabai Nan Aluih, "Ampunlah ambo mandeh kanduang, pihak kapado tanyo mandeh, denai nan indak tahu pandai, mandeh nan lupo tantang itu.

Bakato pulo Sabai Saridun, "Danga di anak mandeh katokan, kok naiak urang ka ateh rumah, bia inyo rancak atau buruak, sambuiklah jo muko manih, mintak duduak inyo dahulu, latakkan siriah ka dikunyah, 
latakkan ayia ka diminum, pinang kok alah digatoknyo, tanyo di anak baiak-baiak, apo ujiang jo sangajo. Salasai barundiang sakirokiro, di sinan baru anak lapeh, supayo sanang di hatinyo.

Kok tumbuah alek jo jamu, di dalam korong kampuang urang, panggilan usah anak tulak, adatnyo diisi limbagonyo dituang.

Adat limbago anak gadih, jan duduak atek pintu, jan sangingik-i, iyo jo anak bujang urang, buruak cando dipandang mato, randah gengsi sabab dek itu (hlm. 11-13).

As a biological child, do you know the traditional children of Minangkabau women, the Bekorong and Bakampung customs?

Answering Sabai Nan Aluih, "Forgive me, Mother, I don't know the question, you haven't taught me.

Sabai Nan Aluih also said, hearing the mother's child say, if someone comes into the house (guest), let them be beautiful or ugly, welcome them with a clear face, let them sit down, put betel nut to chew, put the water for drink, if the betel nut has been eaten, ask the children nicely what is their purpose. If the discussion is done, let them to go back home. To make their heart happy.

If there is an invitation or a banquet, in the people's village hall, fulfill the invitation by bringing it according to the limbago custom.

Girls' limbago custom, don't sit at the door, don't tease people's boys, bad to be look at, and it lead to low prestige.

The data above is a conversation between Sadun Saribai and Sabai Nan Aluih. Sadun Saribai as a mother advises her son on the customs of women's limbaga in Minangkabau. This can be seen in "If someone comes into the house (guest), let them be beautiful or ugly, welcome them with a clear face, let them sit down, put betel nut to chew, put the water for drink, if the betel nut has been eaten, ask the children nicely what is their purpose. If the discussion is done, let them to go back home. To make their heart happy If there is an invitation or a banquet, in the people's village hall, fulfill the invitation by bringing it according to the limbago custom. Girls' limbago custom, don't sit at the door, don't tease people's boys, bad to be look at, and it lead to low prestige". With his loving and nurturing character, Sadun Saribai is grouped into ragam orang with categories of orang. Orang are normal people who feel the bad and the good, the high and the low, the dark and the light just like everyone else. Sadun Saribai with such a loving character, pays attention to and educates her son. As a mother, Sadun Saribai will feel bad if her child does not know how the customary institutions in Minangkabau are, such as the custom of visiting, fulfilling invitations, girls are not allowed to sit at the door, and are not allowed to seduce men. Sadun Saribai will feel better if her son knows about the customs of their country. People who have a high position are people who respect customs and implement them in daily life, so they know the light and dark of this life. This is what groups Sadun Saribai into a variety of ragam orang with categories of orang. 
Data 2

Bakato Sadun Saribai, "Anak kanduang Sabai Nan Aluih, pamenan mato patang pagi, ubek jariang palarai damam, pincuran darah di kaniang, sibiran tulang nan suok, ka mari malah duduak, ado nan $k a$ mandeh katokan...

"Denai tiliak denai pandangi, anak rintang di ateh anjuang sajo, rintang malukih jo batanun, indak tahu badan lah gadang. Sabagai lai nak kanduang, alah koh anak tahu pandai, adat limbago parampuan, adat bakorong jo kampuang?"

Manjawab Sabai Nan Aluih, "Ampunlah ambo mandeh kanduang, pihak kapado tanyo mandeh kanduang, pihak kapado tanyo mande, denai nan indak tahu pandai, mandeh nan lupo tantang itu (hlm.11-12).

Said Sadun Saribai, 'Sabai Nan Aluih's biological son, mata petang pagi games, fatigue medicine to relieve fever, blood splatter on the forehead, sibiran right bone, come sit down, I have something to say...

I saw my mother looking at the child that busy on the anjung, painting and weaving, didn't know they had grown up. Are the children smart, the traditional limbago of women, the tradition of berkorong dan berkampung? Replying to Sabai Nan Aluih, "Forgive me mother about your wonder, I don't know, you are who forgot about it.

This second data are the conversations between Sadun Saribai (Sabai Nan Aluih's mother) and Sabai Nan Aluih. This can be seen in Sabagai lai nak kanduang, alah koh anak tahu pandai, adat limbago parampuan, adat bakorong jo kampuang? (Are the children smart, the traditional limbago of women, the tradition of berkorong dan berkampung?). From this conversation, it can be seen that Sadun Saribai's character is compassionate. With his loving nature, Sadun Saribai is grouped into ragam orang with categories of orang. Orang are normal people who feel the bad and the good, the high and the low, the dark and the light just like everyone else. Sadun Saribai with such a loving character, cares for and educates his children. As a mother, Sadun Saribai will feel bad if her child does not know about the customs of institutions in Minangkabau, and on the contrary will feel good if her child knows about the customs of her country. People who have a high position are people who respect customs, so they know the light and dark of this life. This is what groups Sadun Saribai into a variety of ragam orang with categories of orang.

Data 3

Birawari Sadun Saribai, dek adab pado suami, tunduak manakua inyo lai, tapi taraso dalam hati, kok mukasuik lai sarupo, ato jalannyo indak saroman, anak disuruah di paneh garang, kok timbua sakik ngilu paniang, mandeh ko juo maidokkan (hlm. 20).

Sadun Saribai has been mentioned because of her attitudes to his husband, she bowed down to him again, but it felt deep in her heart, if the intentions are the same, or the path is not the same, the 
child is ordered to be in the heat, if the child is sick, dizzy, mande will also take care of it.

This third data are Sadun Saribai's behavior, namely tunduak manakua inyo lai (bowed to him again). This behavior was carried out by Sadun Saribai when she listened to her husband's words. This shows that Sadun Saribai includes a variety of ragam orang with categories of orang. Orang are normal people who feel the bad and the good, the high and the low, the dark and the light like everyone else, and feel ashamed if they can't be like other people. As a wife Sadun Saribai can feel good, that her husband's words must be heard. The husband is the head of the family, so Sadun Saribai can feel that her husband is above her. The husband certainly knows what is good for his family and Sadun Saribai respects her husband's decision, even though it is against her conscience.

Data 4

Birawari Sadun Saribai, dek adab pado suami, tunduak manakua inyo lai, tapi taraso dalam hati, kok mukasuik lai sarupo, ato jalannyo indak saroman, anak disuruah di paneh garang, kok timbua sakik ngilu paniang, mandeh ko juo maidokkan (hlm. 20).

Sadun Saribai has been mentioned because of her attitudes to her husband, she bowed down to him again, but it felt deep in her heart, if the intentions are the same, or the path is not the same, the child is ordered to be in the heat, if the child is sick, dizzy, the mother will also take care of it.

The fourth data explains Sadun Saribai's feelings as a wife, tapi taraso dalam hati, kok mukasuik lai sarupo, ato jalannyo indak saroman, anak disuruah di paneh garang, kok timbua sakik ngilu paniang, mandeh ko juo maidokkan (but it felt deep in her heart, if the intentions are the same, or the path is not the same, the child is ordered to be in the heat, if he is sick, dizzy, the mother will also take care of it). Sadun Saribai's inner monologue occurred when she had different thoughts from her husband Rajo Babandiang in educating their son Mangkutak Alam. As a wife, she must obey her husband. Although their intentions are the same, both for the good of the child, but the method is different. Mothers prioritize feelings in educating children, while fathers use logic more. The father told the children to play, to be strong and withstand the hot weather. Meanwhile, mothers feel sorry for their children playing in the scorching heat. If the child is sick, the mother will also take care of it and not the father. From this inner monologue, Sadun Saribai has a patient character and belongs to ragam orang with various categories of orang. Orang are normal people who feel the bad and the good, the high and the low, the dark and the light just like everyone else. The person will feel ashamed if he can not be the same as other people. Sadun Saribai feels bad when her son plays in the scorching heat. She also felt good from her husband's good intentions who allowed Mangkutak Alam to play in the heat so that her son was strong. So, it is not appropriate to play at home. Sadun Saribai also felt that her husband was the priest in the family. His position is higher than her as a wife, she must respect her husband's decision. This shows that Sadun Saribai includes a variety of ragam orang with categories of orang.

\section{CONCLUSION}

From the results of the analysis, it can be concluded that the women in kaba Sabai Nan Aluih which are Sabai Nan Aluih and Sadun Saribai, belong to the variety of ragam orang with categories of orang. These two characters are normal people who feel the bad and the good, the high and the low, the dark and the light like other people and feel ashamed if they can't be the same as others. Sabai Nan Aluih belongs to the a variety of ragam orang with 
categories of orang because he dared to defend her father's death, she was firm in his actions, she felt anxious that something bad would happen to her father, she was responsible for her brother and father's corpse, and acted wisely. Because of Sadun Saribai loves her family, educates her children to understand the customs of limbago in Minangkabau, respects her husband's decisions, and also patient. As a bundo kanduang, Sadun Saribai is not a determinant in the family. She respects and carries out her husband's decisions.

In this $k a b a$, there is a Minangkabau women's limbago custom which are women must be skilled (weaving and painting), respect guests, fulfill invitations, may not sit at the door, and may not seduce men.

\section{AUTHOR'S CONTRIBUTION}

In this study, researchers examined the variety of Ragam Orang in kaba Sabai Nan Aluih. This study examines the intrinsic element which is the characterizations in the kaba. The researcher uses a structural theory that is different from the characterization theory that is usually used, such as Abrams theory, Altenbernd and Lewis theory, and Kenny theory. The theory that the researcher uses is the Navis theory which is called the variety of ragam orang. This theory sees characters with four categories which are orang, takah orang, angkuh orang, and orang-orang. The researcher uses this Navis theory because what is being studied is kaba with a Minangkabau cultural background and a variety of ragam orang is a theory that departs from the teachings of Minangkabau philosophy. Therefore, in analyzing literary works, you can use a theory that has a relationship between the object under study and the theory used.

\section{ACKNOWLEDGMENTS}

The researchers thank the Dean of the Faculty of Cultural Sciences, Hasanuddin University, Head of the Indonesian Literature Study Program at the Doctoral Education Level (S3), and lecturers at the Faculty of Cultural Sciences, Hasanuddin University for their knowledge and guidance. May we all be given health by Allah... Aamiin Ya Robbal Aalamiin.

\section{REFERENCES}

[1] Navis, A. A. 1986. Alam Terkembang Jadi Guru. Jakarta: Pustaka Grafitipers.

[2] Djamaris, Edwar. 2002. Pengantar Sastra Rakyat Minangkabau. Jakarta: Yayasan Obor Indonesia.

[3] Bakar, Jamil. 1981. Sastra Lisan Minangkabau. Jakarta: Departemen Pendidikan dan Kebudayaan.

[4] Aimifrina. 2013. "Minangkabau dalam Kaba Cindua Mato". Dalam Jurnal Widyaparwa. Nomor 2, Volume 41, hlm. 111-121, Desember 2013. Yogyakarta: Balai Bahasa Provinsi Daerah Istimewa Yogyakarta.

[5] Jabrohim (Ed.). 2003. Metodologi Penelitian Sastra. Yogyakarta: Hanindita.

[6] Ratna, Nyoman Kutha. 2004. Teori, Metode, dan Teknik Penelitian Sastra dari Strukturalisme hingga Postrukturalisme Perspektif Wacana Naratif. Yogyakarta: Pustaka Pelajar. 